\title{
A KINETICAL APPROACH OF TEXTURE CHANGES OF VEGETABLES DURING BLANCHING
}

\author{
A. SEBÖK, P. BONTOVICS and M. BLESZKÁN \\ Campden \& Chorleywood Food Industry Development Institute Hungary, \\ H-1094 Budapest, Márton u. 3/b. Hungary
}

(Received: 27 November 1998; accepted: 22 March 1999)

The texture changes during the initial phase of blanching of potatoes, carrots and green peas at different blanching times $(0-240 \mathrm{~s})$ and temperatures $\left(85^{\circ} \mathrm{C}, 95^{\circ} \mathrm{C}, 100^{\circ} \mathrm{C}\right)$ were investigated. The breaking force $(\mathrm{N})$ was determined by compression or Back extrusion tests with an Instron texture tester. Electronmicroscopic studies (SEM) were made to support the interpretation of the results.

For each vegetable several sections of changes of the breaking force $(\operatorname{lnF})$ were identified. For potatoes a three phase change of the breaking force by all temperatures $\left(85^{\circ} \mathrm{C}, 95^{\circ} \mathrm{C}, 100{ }^{\circ} \mathrm{C}\right)$ was observed. In the first of the 3 different observed stages of potato blanching the breaking forces increased with time $(0-40 \mathrm{~s})$. In the second and third stage of the blanching process of potato a linear relationship was found between the logarithm of the breaking force and the blanching time. The second phase observed was faster $(40-160 \mathrm{~s})$ than the consecutive slower third phase (160-240 s).

For green peas the change of the breaking force $(\operatorname{lnF})$ can be described by two consecutive first rate reactions. A faster decreasing period between $0-25 \mathrm{~s}$ was followed by a slower decreasing one between 70-140 s. Between the first and second stage of the blanching process there was an initial lag period (25-70 s), which will not be described here. In the period after $140 \mathrm{~s}$, there was not any change, this period is constant.

For carrots the fastest change can be observed at $100{ }^{\circ} \mathrm{C}$ compared to the results at 85 and $95^{\circ} \mathrm{C}$. A three-phase curve was observed as well. An initial lag period $(0-90 \mathrm{~s})$ was followed by a faster (90-190 s) and a slower (190-240 s) decreasing one. In the second and third stage of the blanching process of carrots a linear relationship was found. For the changes of the breaking force $(\operatorname{lnF})$ a kinetical approach was applied, reaction rate constants and apparent activation energies were calculated. The kinetical approach helps to compare and forecast changes at different process conditions.

Keywords: blanching, microstructure, reaction rate, texture, vegetables

The softening of texture of vegetables during blanching was described in details, but less information is available about the process and kinetics of the changes. Most of the authors described the kinetics of the softening by a single first order reaction (BOURNE, 1976; HARADA et al., 1985a, b). HARADA and PAULUS (1987) used first order 
kinetics to describe the changes of shear force of potatoes at different cooking parameters. KOZEMPEL (1988) found lag periods before the first order equation was applied for the changes of Back extrusion peak forces of potato samples during cooking. The Arrhenius plot was used to calculate kinetic constants. VERLINDEN and co-workers (1995) developed a compartmental kinetic texture model for potatoes during cooking, where all texture changes related to the degradation of the cell wall were described by an apparent first order reaction and the effect of starch gelatinization was described with an other first order reaction.

In plant tissues softening of the texture by cooking is caused by several factors: the loss of turgor pressure and occluded air, the degradation of middle lamella pectin and other cell wall polysaccharides and starch gelatinization (AGUILERA \& STANLEY, 1990).

STANLEY and co-workers (1995) reported that in beans and carrots the main reason of softening was the thermal degradation of the middle lamella, which resulted in separation of the cells.

BOURNE (1987) found that during blanching of carrots and green beans between 0-40 min cooking time a rapid softening was observed in the first period, followed by a nearly linear softening. He proved that the softening curves are similar at higher and lower temperatures, however the actual firmness values differed significantly.

The objective of this study was to describe the first transitional period of textural changes during blanching, and to use these results for the interpretation of the changes.

\section{Materials and methods}

Potatoes (variety Desire; storage $10^{\circ} \mathrm{C}$ ), carrots (variety Chatenay; storage $10{ }^{\circ} \mathrm{C}$ ) and green peas (variety Polar; storage $10^{\circ} \mathrm{C}$ ) from the regular supply of the Hungarian frozen food industry were used as test samples.

From potatoes cylindrical specimens (height $14 \mathrm{~mm}$, diameter $25 \mathrm{~mm}$ ) were cut out with a starch content of $14-17 \%$ and dry substance of $22-24 \mathrm{~g} / 100 \mathrm{~g}$.

Green peas were used after vining and sieving. The starch content varied between $17.5-17.75 \%$, the dry substance between $22.9-23.4 \mathrm{~g} / 100 \mathrm{~g}$ and the size between 8-9 mm.

From carrots cylindrical specimens (height $14 \mathrm{~mm}$, diameter $25 \mathrm{~mm}$ ) from xylem were cut. The dry substance of carrots was determined between $13-13.5 \mathrm{~g} / 100 \mathrm{~g}$.

Samples $\left(15\right.$ parallel) were blanched in hot water at $85^{\circ} \mathrm{C}, 95^{\circ} \mathrm{C}, 100^{\circ} \mathrm{C}$ within a temperature regulated laboratory waterbath $(5 \mathrm{l})$. Individual pieces $(5$ samples) of potatoes and carrots or a bulk of peas were taken out of the waterbath at different time intervals $(5-240 \mathrm{~s})$ and cooled in the air flow at $20^{\circ} \mathrm{C}$ before the measurements were made. 
The breaking force ( 15 samples) was determined at $25^{\circ} \mathrm{C}$ by compression of individual cylinders of carrots and potatoes by an Instron 1140 Texture Tester (crosshead speed $200 \mathrm{~mm} \mathrm{~min}^{-1}$ ) with a cylindrical probe (diameter: $57 \mathrm{~mm}$ ) as the first peak on the force-deformation curve. For green peas the average height of the plateau of a Back Extrusion test was determined (crosshead speed $200 \mathrm{~mm} \mathrm{~min}^{-1}$, cell gap: $4 \mathrm{~mm}$ ).

The breaking force values measured by Instron were plotted against blanching time (Fig. 1, A). Results were plotted as 1n F-t (Fig. 1, B), and kinetical rate constants were calculated from the linear part at different temperatures. The dependence of logarithmed breaking force on blanching time as described by the following equation is:

$$
\ln \mathrm{F}_{\mathrm{t}}=\ln \mathrm{F}_{0}-\mathrm{k} \times \mathrm{t}
$$

where $F_{t}$ is the breaking force at any time $t(N), F_{0}$ is the breaking force of unblanched vegetables $(\mathrm{N}), \mathrm{k}$ is the kinetical rate constant $\left(\mathrm{min}^{-1}\right)$, $\mathrm{t}$ is the blanching time ( $\left.\mathrm{min}\right)$.

The apparent activation energies were calculated from the slope of the $1 \mathrm{n} \mathrm{k-1/T}$ plot as well (Fig. 1C). The dependence of kinetical rate constant on blanching temperature as described by the following equation is:

$$
\operatorname{lnk}_{\mathrm{t}}=\operatorname{lnk}_{0}-\mathrm{E}_{\mathrm{a}} / \mathrm{R} \times 1 / \mathrm{T}
$$

where $\mathrm{k}_{\mathrm{t}}$ is the kinetical rate constant at any time $\left(\min ^{-1}\right), \mathrm{k}_{0}$ is the kinetical rate constant of unblanched vegetables $\left(\mathrm{min}^{-1}\right), \mathrm{E}_{\mathrm{a}}$ is the apparent activation energy $\left(\mathrm{J} \mathrm{mol}^{-1}\right), \mathrm{R}$ is the gas constant $\left(1.987 \mathrm{~J} \mathrm{~mol}^{-1}\right)$, $\mathrm{T}$ is the absolute temperature $(\mathrm{K})$.

For the electron microscope studies the method of DAVIS and GORDON (1980) was followed: The samples were fixed with glutaraldelyd, washed with phosphate buffer, fixed with osmiumtetraoxide, washed with phoshate buffer and dehydrated with acetone, followed by dehydration with liquid $\mathrm{CO}_{2}$ in BALZERS CPD 020. The dried samples were gold covered by BALZERS SCD 040 as in BONTOVICS \& SEBŐK, 1999). For the electron microscopy studies a TESLA BS 300 scanning electron microscope was used $(20 \mathrm{kV})$.

\section{Results}

The results showed that the process of texture changes during blanching of vegetables can be described by several phases and different patterns can be observed for different vegetables. 


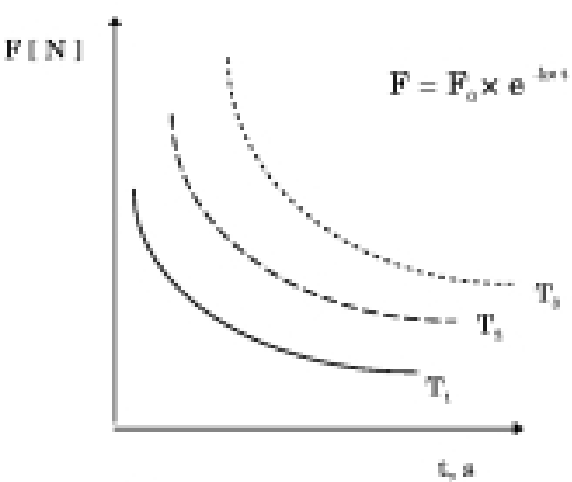

A)

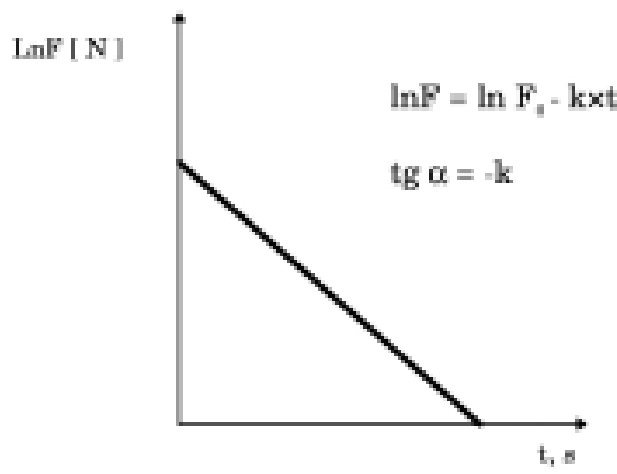

B)

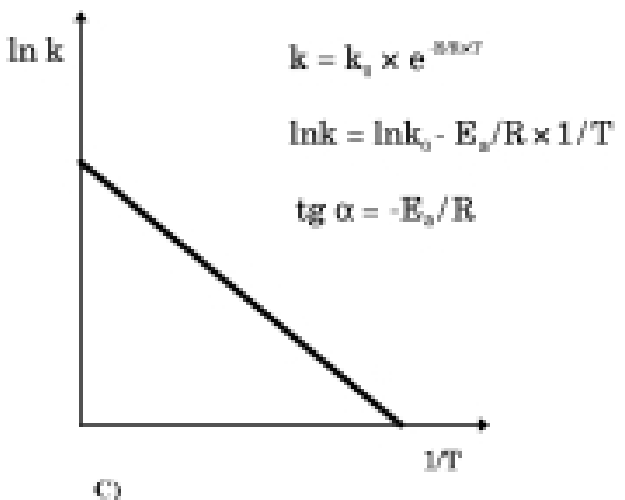

Fig. 1. Kinetical approach. $F_{t}$ : breaking force at any time $t ; F_{0}$ : breaking force of unblanched vegetables; $\mathrm{k}$ : kinetical rate constant; $\mathrm{k}_{\mathrm{t}}$ : kinetical rate constant at any time; $\mathrm{k}_{0}$ : kinetical rate constant of unblanched vegetables; t: blanching time; $\mathrm{E}_{\mathrm{a}}$ : apparent activation enegry; $\mathrm{R}$ : gas constant; $\mathrm{T}$ : absolute temperature 
For potatoes (Fig. 2) a slight increase of the breaking force was observed at the initial phase $(0-40 \mathrm{~s})$. At this phase higher blanching temperature results in higher maximum value. This first period (I. phase between $0-40 \mathrm{~s}$ ) is followed by two linear phases on the semilogarithmic plot, the second phase (II. phase between 40-160 s) shows faster, the third phase (III. phase between $160-240$ s) slower softening at $85^{\circ} \mathrm{C}$, where the difference of softening rate of the second and third phases wasn't significant, but the correlation coefficient shows that the three phases practically can be used, for a kinetical approach (BONTOVICS \& SEBÖK, 1999).

Higher blanching temperature results in softer texture and faster softening rate. The apparent activation energies for these two linear phases (II. and III. phases) are of similar magnitude $\mathrm{E}_{\mathrm{II}}(40-160 \mathrm{~s})=56.94 \mathrm{~kJ} \mathrm{~mol}^{-1}$ and $\mathrm{E}_{\mathrm{III}}(160-240 \mathrm{~s})=$ $58.24 \mathrm{~kJ} \mathrm{~mol}^{-1}$ (Table 1).

For green peas four phases were observed as well (Fig. 3.). A rapid softening in the first phase (I. phase) $25 \mathrm{~s} \mathrm{E}_{\mathrm{I}}(0-25 \mathrm{~s})=89.27 \mathrm{~kJ} \mathrm{~mol}^{-1}$ was followed by a lag period in the second $(25-70 \mathrm{~s})$ and a slower decrease in the third (III. phase) $\mathrm{E}_{\mathrm{III}}(70-140 \mathrm{~s})=$ $28.36 \mathrm{~kJ} \mathrm{~mol}^{-1}$ phases (Table 1), and then it ended (IV. phase between 140-240 s) in a very slow softening in the last period at all temperatures.

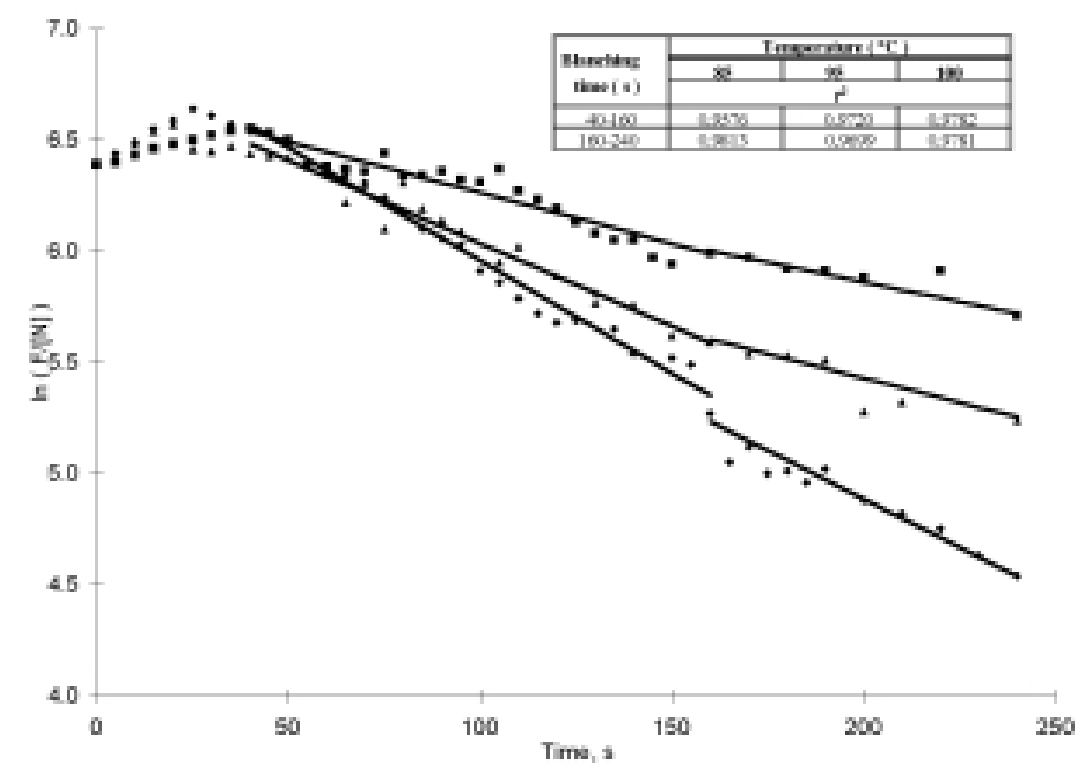

Fig. 2. Changes of the breaking force during blanching of potatoes. $\mathbf{\square}: 85^{\circ} \mathrm{C}, \quad \mathbf{\Delta}: 95^{\circ} \mathrm{C}$, จ: $100^{\circ} \mathrm{C}, 0-240 \mathrm{~s}$ 
For carrots a three phase softening was observed as well (Fig. 4). In case of carrots a lag period was observed in the first $90 \mathrm{~s}$, the texture is not constant even during the lag period, but an initial increase of firmness is followed by a decrease and an increase again before the faster softening period starts. Apparent activation energies were $\mathrm{E}_{\mathrm{II}}(90-190 \mathrm{~s})=159.56 \mathrm{~kJ} \mathrm{~mol}^{-1}$ and $\mathrm{E}_{\mathrm{III}}(190-240 \mathrm{~s})=66.99 \mathrm{~kJ} \mathrm{~mol}^{-1}($ Table 1$)$ respectively.

Electron microscopic photographs help to interpret the texture changes. During the cooking of potatoes at $100{ }^{\circ} \mathrm{C}$ (Fig. 5) at $30 \mathrm{~s}$ (Fig. 5b) the parenchyma cells are swollen as a result of the diffusion of water into the tissues but the cell walls are intact. These pictures explain that the first increase of the breaking force can be caused by the increased internal pressure of the tissues as a result of water uptake.

At $60 \mathrm{~s}$ (Fig. 5c) starch granules start to swell, and the thermal destruction of the cell walls has been started. Between $90-120 \mathrm{~s}$ (Fig. 5d-e) the rapid progress of thermal destruction of the middle lamella is well observable, while the swelling and gelatinization of the starch continue.

Between 160-180 s (Fig. 5f-g) the cell structure disappears and the process of starch gelatinization is nearly complete, which explains the third phase of the texture changes. At this phase the volume and the weight loss of the potatoes are nearly constant. This third phase is the initial part of that long softening period, which is described as nearly linear in a semilogarithmic plot in the majority of the studies, where larger time span of potato cooking (0-40 min) was investigated (HARADA et. al., 1985a; KOZEMPEL, 1988).

These results support the assumption that the softening of potato is caused mainly by the thermal destruction and decomposition of the pectin material and other cell wall polysaccharides, and by cell separation, while starch gelatinization has a secondary effect only.

For green peas where turgor pressure and starch structure have much more significance the first (Fig. $3,0-25 \mathrm{~s} 85^{\circ} \mathrm{C}, 95^{\circ} \mathrm{C}, 100{ }^{\circ} \mathrm{C}$ ) rapid decrease of the breaking force can be explained by the loss of turgor, and the start of the thermal destruction of the cell wall. This is well supported by the electron microscopic photographs (Fig. 6). At $25 \mathrm{~s}$ (Fig. 6b,c,d) starch granules start to swell and the process of starch gelatinization at $10{ }^{\circ} \mathrm{C}$ (Fig. 6d) is nearly complete. The second phase (Fig. 3 $70-140 \mathrm{~s}$ ) of the reduction of the breaking force may be caused by the gelatinization of the starch (the gelatinization of the starch continues Fig. 6e,f,g), while the third phase can be characterised by the progress of the thermal decomposition of the cell walls (Fig. 6h,i,j). 


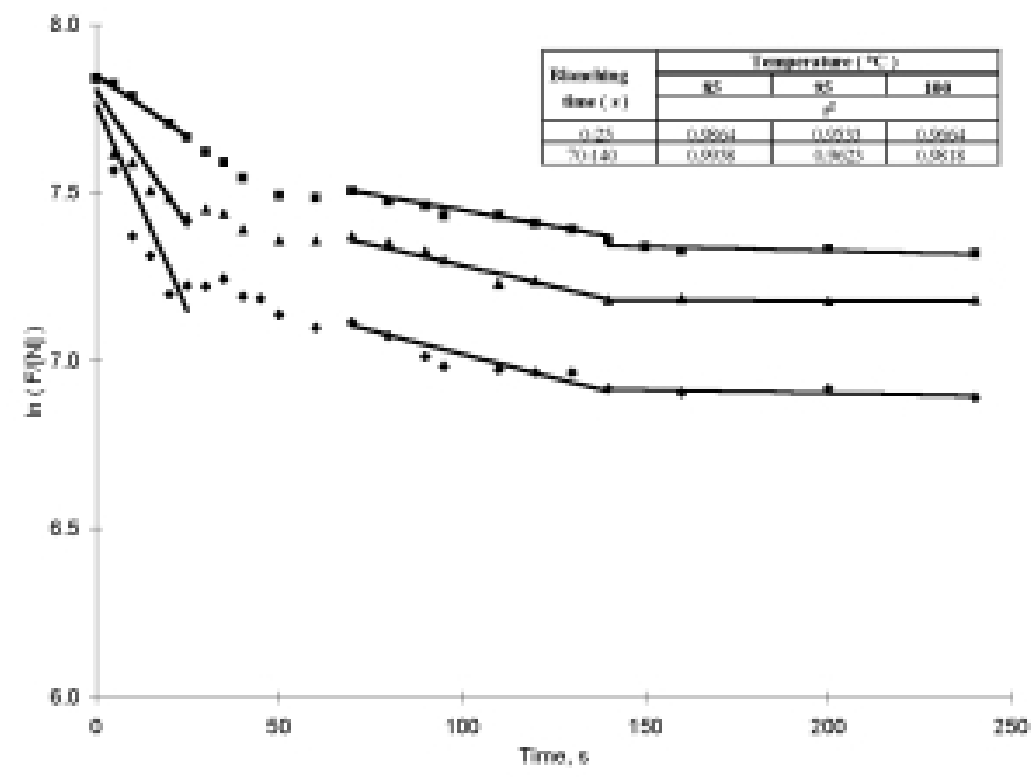

Fig. 3. Changes of the breaking force during blanching of green peas. $\mathbf{\square}: 85^{\circ} \mathrm{C}, \boldsymbol{\Delta}$ : $95^{\circ} \mathrm{C}$, ४ $100{ }^{\circ} \mathrm{C}, 0-240 \mathrm{~s}$

For carrots the two processes i.e. the swelling of cells (Fig. $7 \mathrm{~b}, \mathrm{c}$ ) caused by diffusion of water into the cells and the loss of turgor take place nearly parallelly (Fig. 7d,e), which result in the first apparent lag period. The phase of permanent softening may be connected to the heat destruction of the cell structure of the tissue, while the third phase may represent a slower decomposition of the cell wall polysaccharides (Fig. 7f,g). 


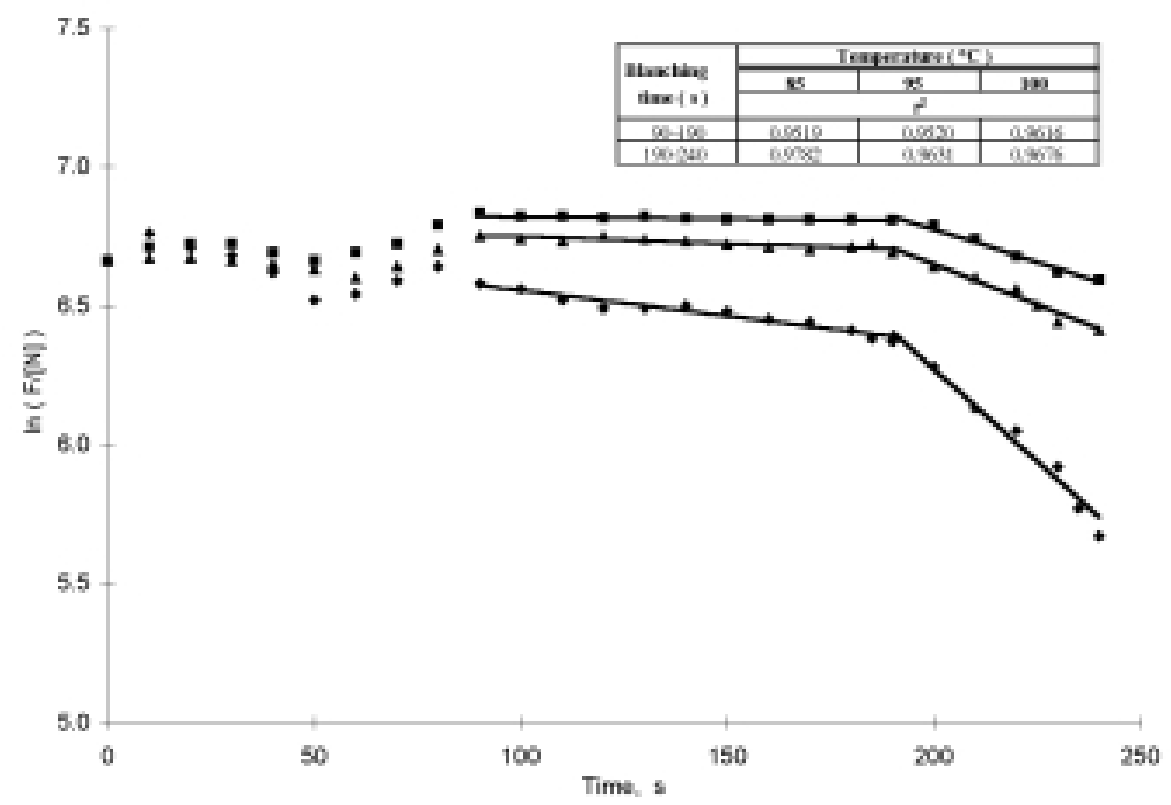

Fig. 4. Changes of the breaking force during blanching of carrots. $\mathbf{\square}: 85^{\circ} \mathrm{C}, \boldsymbol{\Delta}$ : $95^{\circ} \mathrm{C}$, ४: $100^{\circ} \mathrm{C}, 0-240 \mathrm{~s}$

Table 1

Apparent activation energies

\begin{tabular}{cc}
\hline Blanching time (s) & Activation energies $\left(\mathrm{kJ} \mathrm{mol}^{-1}\right)$ \\
\hline & Potatoes \\
\hline $40-160$ & 56.94 \\
$160-240$ & 58.24 \\
\hline & Green peas \\
\hline $0-25$ & 89.27 \\
$70-140$ & 28.36 \\
\hline & Carrots \\
\hline $90-190$ & 159.56 \\
$190-240$ & 66.99 \\
\hline
\end{tabular}

Acta Alimentaria 28, 1999 

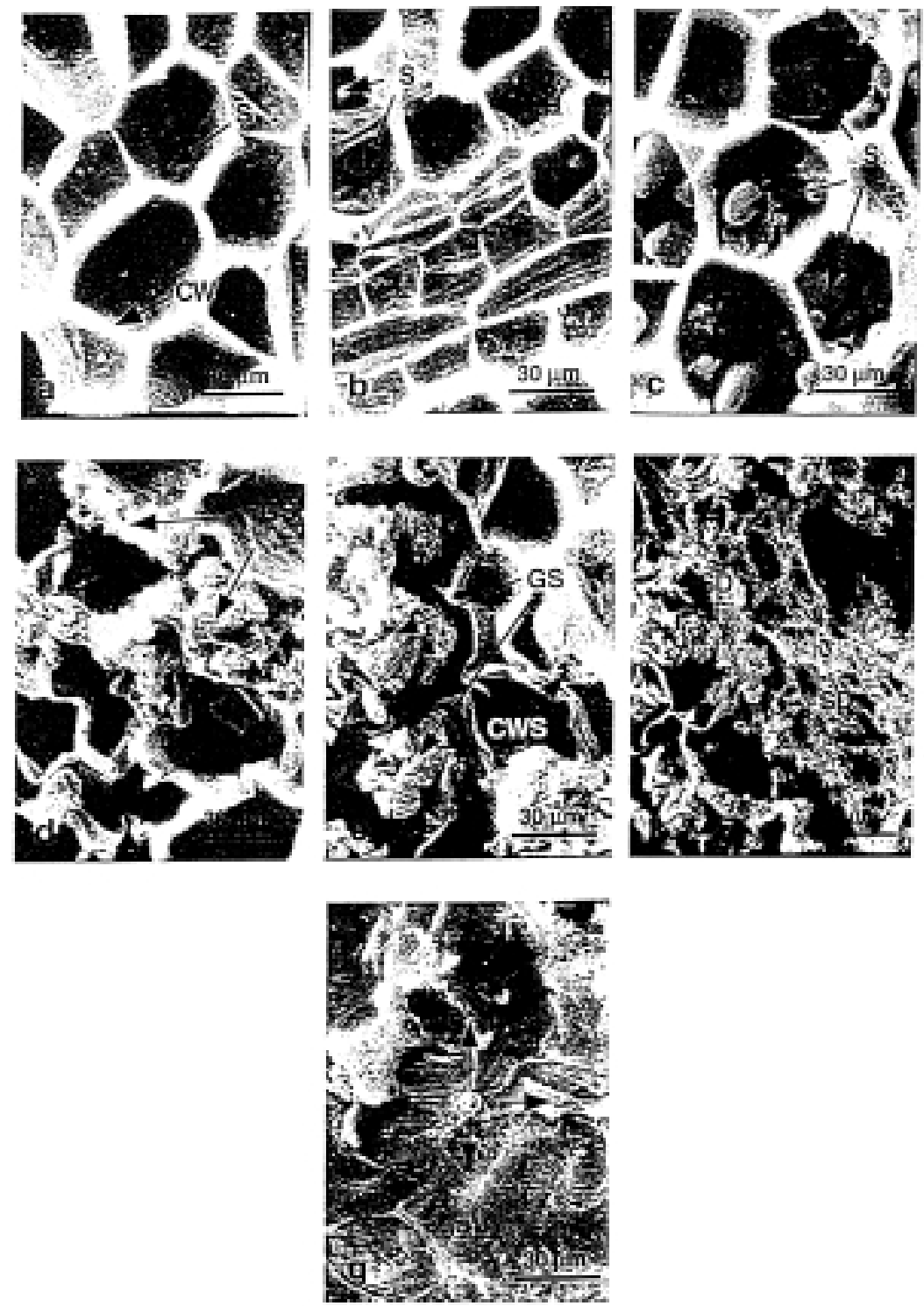

Fig. 5. Ultrastructure (SEM) of the blanched potato tissue (in water $100^{\circ} \mathrm{C}$ ). a: raw; b: $100{ }^{\circ} \mathrm{C}, 30 \mathrm{~s}$; $\mathrm{c}$ : $100{ }^{\circ} \mathrm{C}, 60 \mathrm{~s} ; \mathrm{d}: 10{ }^{\circ} \mathrm{C}, 90 \mathrm{~s}$; e: $100{ }^{\circ} \mathrm{C}, 120 \mathrm{~s} ;$ f: $100^{\circ} \mathrm{C}, 160 \mathrm{~s} ; \mathrm{g}: 100{ }^{\circ} \mathrm{C}, 180 \mathrm{~s}$; S: starch granule; GS: gelatinized starch; $\mathrm{SD}$ : structural damage; $\mathrm{CW}$ : cell wall; $\mathrm{CWS}$ : cell wall separation 

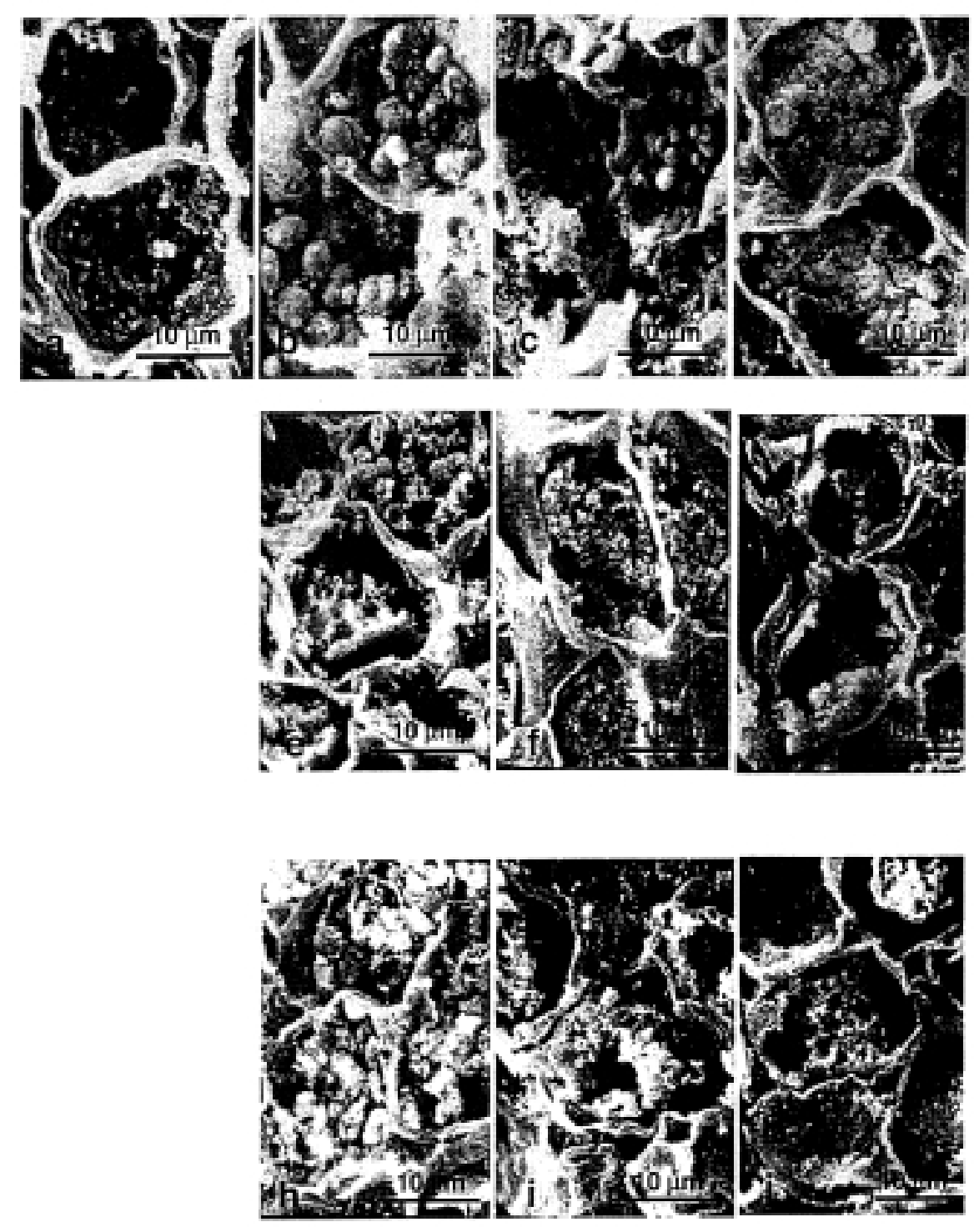

Fig. 6. Ultrastructure (SEM) of the blanched green peas tissue (in water $85^{\circ} \mathrm{C}, 95^{\circ} \mathrm{C}, 100^{\circ} \mathrm{C}$ ). a: raw; b: $85^{\circ} \mathrm{C}, 25 \mathrm{~s} ;$ c: $95^{\circ} \mathrm{C}, 25 \mathrm{~s}$; d: $100{ }^{\circ} \mathrm{C}, 25 \mathrm{~s} ;$ e: $85^{\circ} \mathrm{C}, 150 \mathrm{~s}$, f: $95^{\circ} \mathrm{C}, 150 \mathrm{~s} ; \mathrm{g}: 100{ }^{\circ} \mathrm{C}, 150 \mathrm{~s} ; \mathrm{h}: 85^{\circ} \mathrm{C}$, $240 \mathrm{~s}$; i: $95^{\circ} \mathrm{C}, 240 \mathrm{~s}$; j: $100^{\circ} \mathrm{C}, 240 \mathrm{~s}$ 

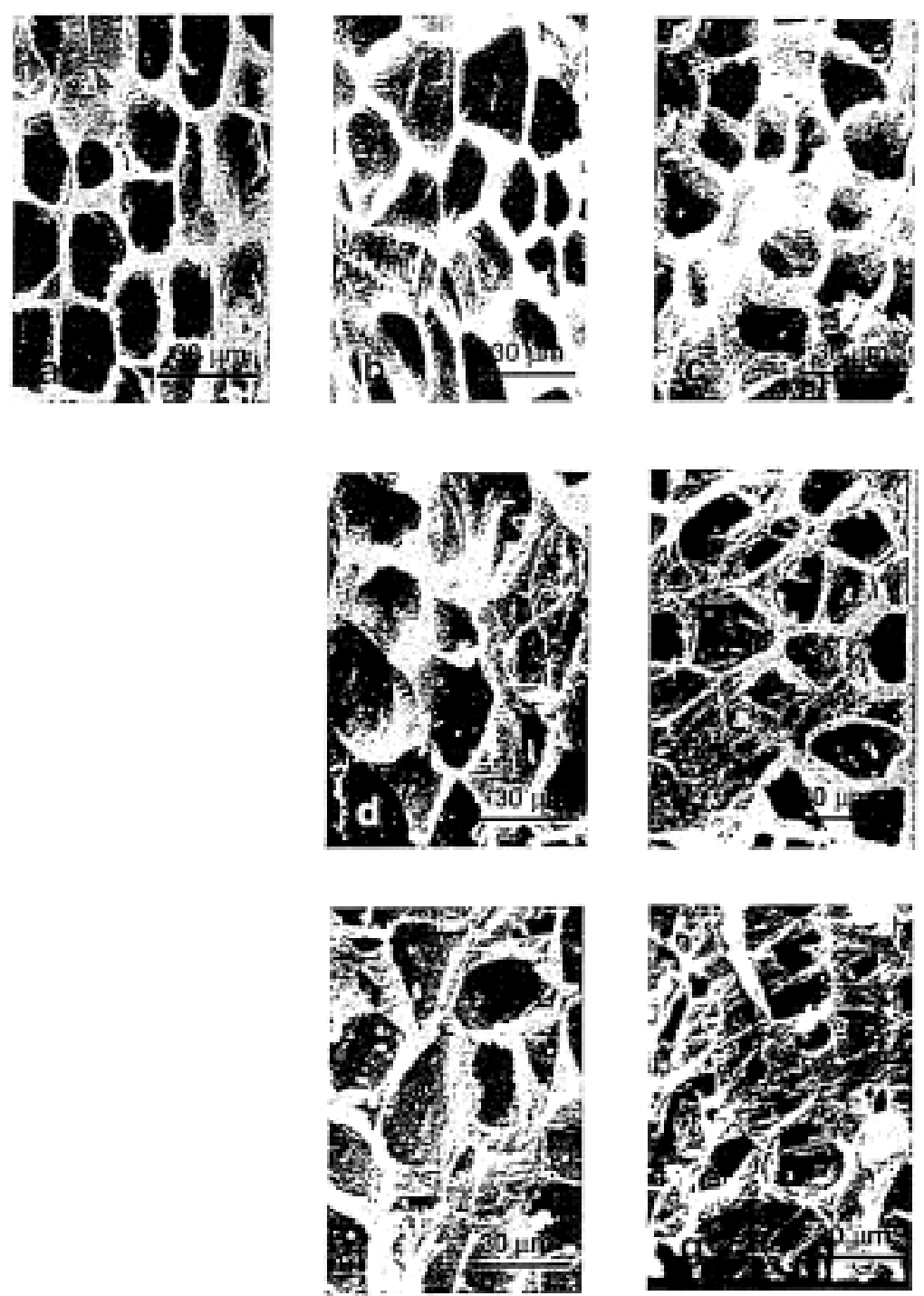

Fig. 7. Ultrastructure (SEM) of the blanched carrot tissue (in water $95^{\circ} \mathrm{C}, 100^{\circ} \mathrm{C}$ ). a: raw; b: $95{ }^{\circ} \mathrm{C}, 60 \mathrm{~s}$; c: $100{ }^{\circ} \mathrm{C}, 60$ s; d: $95^{\circ} \mathrm{C}, 120 \mathrm{~s}$; e: $100{ }^{\circ} \mathrm{C}, 120 \mathrm{~s} ;$ f: $95^{\circ} \mathrm{C}, 240 \mathrm{~s} ; \mathrm{g}: 100{ }^{\circ} \mathrm{C}, 200 \mathrm{~s}$ 


\section{Conclusions}

Results proved that the investigation of the initial transient phases of blanching of different vegetables provides useful information for the interpretation of the processes causing changes in the microstructure.

For each vegetable the texture change in the initial part of the blanching processes can be described as combinations of different sections. Most of these individual sections can be approximated by first rate kinetics.

These results confirmed that the softening of texture during blanching is mainly influenced by the thermal destruction of cell wall polysaccharides - potatoes, carrots but the loss of turgor (peas, carrots, potatoes) and starch gelatinization may have an influence, which is significant in case of peas and less pronounced for potatoes.

The kinetical approach of the processes - the calculation of reaction rates and apparent activation energies - provides a valuable tool for comparison of the experimental curves and for better interpretation of the results.

This research was carried out within a project funded by OTKA 845 .

\section{References}

AGUILERA, J. M. \& STANLEY, D. W. (1990): Microstructure of food components. -in: AGUILERA, J. M. \& STANLEY, D. W. (Eds) Microstructural principles of food processing and engineering. Elsevier Applied Science, London and New York, pp. 109-115.

BONTOVICS, P. \& SEBÓK, A. (1999): Studies of the potato microstructure during blanching. Acta Alimentaria, 28, 269-278

BOURNE, M. C. (1976): Texture of fruits and vegetables. -in: DE MAN, J. M., VOISEY, P. W., RASPER, V. F \& STANLEY, D. W. (Eds) Rheology and texture in food quality. AVI Publishing Company, Westport, Connecticut, pp. 275-307.

BOURNE, M. C. (1987): Effect of blanch temperature on kinetics of thermal softening of carrots and green beans. J. Fd Sci., 52, 667-668, 690.

DAVIS, E. A. \& GORDON, J. (1980): Structural studies of carrots by SEM. Scanning Electron Microscopy III., Inc., AMF O’Hare, Chicago, IL 60666., 601-611.

HARADA, T. \& PAULUS, K. (1987): Effects of cooking treatment on the texture of root vegetables. Agric. Biol. Chem., 51, 837-844.

HARADA, T., TIRTOHUSODO, H. \& PAULUS, K. (1985a): Influence of temperature and time in cooking kinetics of potatoes. J. Fd Sci., 50, 459-462, 472.

HARADA, T., TIRTOHUSODO, H. \& PAULUS, K. (1985b): Influence of the composition of potatoes on their cooking kinetics. J. Fd Sci., 50, 463-468.

KOZEMPEL, M. F. (1988): Modelling the kinetics of cooking and pre-cooking potatoes. J. Fd Sci., 53, $753-755$.

STANLEY, D. W., BOURNE, M. C., STONE, A. P. I. \& WiSMER, W. W. (1995): Low temperature blanching effects on chemistry, firmness and structure of canned green beans and carrots. J. Fd Sci., 60 , 327-333.

VERLINDEN, B. E., NiCOLAI, B. M. \& DE BAERDEMAEKER, J. (1995): The starch gelatinization in potatoes during cooking in relation to the modelling of texture kinetics. J. Fd Engng., 24, 165-179. 